\title{
The Impact of Peer Interaction on an Editing Activity in EFL Classes
}

\author{
Sasan Baleghizadeh \\ Department of English Language and Literature, Shahid Beheshti University, G.C., Tehran, Iran \\ Email: sasanbaleghizadeh@yahoo.com
}

\begin{abstract}
This study investigated the merits of peer interaction on a text editing activity in EFL classes in Iran. Sixty-two EFL students majoring in English Literature volunteered to take part in this study. The participants, randomly assigned to experimental and control groups, did the same activity under two conditions: individually and in pairs. The activity required the participants to edit a text containing grammatical errors featuring the use of articles, subordinating conjunctions, and prepositions in English. Data analysis revealed that students' overall performance significantly improved when they worked in pairs than when they did the activity individually. However, their performance did not improve consistently over different grammatical items. As for articles and subordinating conjunctions, pair work improved students' performance. Nevertheless, with respect to prepositions, this phenomenon was not observed.
\end{abstract}

Index Terms - collaboration, negative feedback, peer interaction, pair work

\section{INTRODUCTION}

In recent years, interactionist research, propelled by Long's interaction hypothesis (1983, 1985, 1996), has become one of the most exciting topics of exploration for second language acquisition (SLA) researchers. According to SLA researchers, negotiated interaction is the driving force for language learning in that it provides learners with (a) comprehensible input (Pica, Young \& Doughty, 1987), (b) negative feedback (Gass, 1997; Swain, 1995), and (c) an opportunity to modify their output (Muranoi, 2007; Shehadeh, 2002; Swain, 1995, 2005).

\section{COMPREHENSIBLE INPUT}

Input refers to language that becomes available to the learner through both listening and reading (Gass \& Mackey, 2006). In all approaches to SLA, input is an essential component in the acquisition process in that it provides learners with the crucial evidence from which they can form linguistic hypotheses (Gass \& Mackey, 2007). This suggests that the input available to learners should be comprehensible (Krashen, 1982); otherwise, they cannot form the hypotheses which they need to construct their second language grammars. It is argued that negotiated interaction, especially one in which learners have an opportunity to interact with a more competent interlocutor, say a native speaker, provides them with ample comprehensible input (Pica, 1994, 1996). "As they negotiate, they work linguistically to achieve the needed comprehensibility, whether repeating a message verbatim, adjusting its syntax, changing its words, or modifying its from and meaning in a host of other ways" (Pica, 1994: 494).

An example of how negotiated interaction makes L2 input comprehensible can be seen below (Mackey, 1999: 558559). In this example, the NNS does not understand the word glasses. The word is repeated by the native speaker (NS), the original phrase is extended and rephrased, a synonym is given, and the learner eventually seems to understand what glasses means.

NS: There's there's a pair of reading glasses above the plant.

NNS: A what?

NS: Glasses reading glasses to see the newspaper?

NNS: Glassi?

NS: You wear them to see with, if you can't see. Reading glasses.

NNS: Ahh ahh glasses glasses to read you say reading glasses.

NS: Yeah.

The literature of SLA is abundant with studies which indicate that negotiated interaction makes L2 input comprehensible to learners (see Gass, Mackey \& Pica, 1998; Long, 1996).

\section{NEGATIVE FEEDBACK}

According to Long (1996), negative feedback is an important feature of negotiated interaction. This type of feedback, which occurs as a reaction to a linguistic problem, can come from numerous sources such as teachers, other learners, or even native speakers. According to Gass and Mackey (2007: 181-182), negative feedback includes negotiation strategies such as: 
- Confirmation checks (expressions that are designed to elicit confirmation that an utterance has been correctly heard or understood, for example, Is this what you mean?).

- Clarification requests (expressions designed to elicit clarification of the interlocutor's preceding utterances, for example, What did you say?).

- Comprehension checks (expressions that are used to verify that an interlocutor has understood, for example, Did you understand?).

Thus, negative feedback not only provides learners with information about the accuracy, communicative success, or content of their production, but also helps them notice the gap between their interlanguage and the target language alternative (Gass, 1997; Schmidt, 1990). The following example illustrates an instance of negative feedback in the form of a simple repetition and clarification request:

(" floors?"). The NNS's retrospective comment about the feedback suggests that she noticed a certain gap in her phonology.

NNS: There are/ flurs/?

NS: Floor? « Feedback

NNS: /fluw'rs/ uh Flowers.

NNS: I was thinking my pronounce, pronunciation is very horrible. (Mackey, Gass \& McDonough, 2000: 486)

Another type of negative feedback currently receiving attention in the SLA literature is recasts. According to Nicholas, Lightbown, and Spada (2001: 733), recasts are "utterances that repeat a learner's incorrect utterance, making only the changes necessary to produce a correct utterance, without changing the meaning." Put simply, recasts are the targetlike reformulations of what a learner has just said. The following example indicates how a NS recasts a NNS's utterance.

NNS: Why did you fell down?

NS: Why did you fall down?

NNS: Fall down, yes. (Oliver \& Mackey, 2003: 519)

Some scholars (Long, 1996; Lyster, 1998a, 1998b) have argued that recasts are ambiguous, i.e. while they provide learners with targetlike form, they may be perceived as an alternative way to say the same thing. Thus, learners may not repeat or rephrase their original utterances following recasts, and they do not even perceive recasts as feedback at all (Mackey et al., 2000). However, as Mackey (2007: 92) rightly observes, "the fact that learners sometimes fail to identify feedback as such does not necessarily imply that the feedback is not beneficial for learners." There are a number of studies which suggest that negotiated interaction containing recasts can induce L2 learning (Ayoun, 2001; Braidi, 2002; Leeman, 2003; Mackey \& Philp, 1998).

\section{MODIFIED OUTPuT}

Output refers to the language that learners produce. It is suggested that the feedback learners receive during the process of negotiated interaction pushes them to modify their output (McDonough, 2005; Muranoi, 2007; Shehadeh, 2002; Swain, 1995, 2005). In the example below, two learners are interacting regarding a task that involves finding routes on a map. After producing an initially problematic utterance ("turn another side") and receiving feedback about its lack of comprehensibility, the first learner seems to realize that her utterance was not understood. She then reformulates her initial utterance, modifying her output from "turn another side" to a better grammatical form "turn to the left side." Learner 2 comprehends and thus the conversation goes on.

Learner 1: In front of library, turn another side from grocery store.

Learner 2: Which side from the grocery?

Learner 1: Ah, er turn to the left side. $\leftarrow$ Modified Output

Learner 2: Ok turn left, I did it, now which way to turn? (Mackey, 2007: 93)

Researchers have argued in favor of positive developmental effects when learners modify their output (Gass, 1997; Swain, 1995, 2005). Swain, in particular, has claimed that learners need to be "pushed" to produce more accurate, appropriate, and comprehensible forms after receiving feedback from an interlocutor (see Swain, 1995, 2005). Thus, when interlocutors signal lack of comprehension, learners may reflect upon their language and modify the linguistic and pragmatic features of their output.

All the arguments advanced so far indicate the significance of negotiated interaction in the second language acquisition process. The question of how to foster this type of interaction in second/foreign language classes will be addressed in the next section.

\section{PAIR WORK ACTIVITIES}

Perhaps the most popular way to promote interaction among learners is to use pair work activities. The use of these activities is justified both on pedagogical and theoretical arguments.

According to the pedagogical arguments, pair work activities provide learners with more time to speak the target language, promote learner autonomy, and give teachers opportunities to work with individual learners (Brown, 2001; 
Harmer, 2001; Long and Porter, 1985). Moreover, learners may feel less anxious while interacting with peers than during whole-class discussions (Brown, 2001; Crookes \& Chaudron, 2001; Davis, 1997).

From a theoretical perspective, the use of pair work activities is supported by the interaction hypothesis, briefly elucidated in the preceding sections. Working in pairs provides learners with opportunities to give and receive feedback, and respond to it by modifying their output. Metaphorically, pair work activities create fertile farmland in which the seeds of negative feedback and modified output (both significant features of negotiated interaction) easily grow.

In recent years, a number of studies have been conducted to investigate the merits of learner-learner interaction on various aspects of language learning (see Swain, Brooks \& Tocalli-Beller, 2002 for a comprehensive review). There are a number of studies which have investigated the effect of pair work on grammar tasks (Baleghizadeh, 2009; Storch, 1999, 2007). Storch (1999) found that pair work had a positive effect on overall grammatical accuracy when ESL students in Australia completed a series of grammar-focused exercises (a cloze exercise, a text reconstruction, and a short composition). There were two isomorphic versions to these exercises (i.e., they featured the same theme, the same genre and were the same length and had approximately the same number of similar grammatical points to attend to). The first version was done individually and the other was completed in pairs. In the cloze exercise, accuracy improved in verb tense/aspect choice (from 58\% to 78\%) and particularly in morphology (from $35 \%$ to $84 \%$ ). In the text reconstruction exercise, a greater proportion of items were detected and correctly amended when working in pairs than when working individually ( $72 \%$ vs. $63 \%$ ). With respect to the composition, those written in pairs demonstrated a lower average number of errors than compositions written individually (7.75 vs. 13.6) and a greater proportion of error-free clauses (61\% vs. 47\%). However, as Storch (1999: 371) admits, "these findings are suggestive, given the small scale of this study and number of tokens per grammatical items."

In another study, Storch (2007) investigated the effect of pair work on a text editing task in the same ESL context, i.e. Australia. The text selected for this study contained 19 errors which dealt with the use of verbs, articles, and word forms. Unlike the findings of her previous study, this study revealed a modest difference in the mean accuracy score for those who worked in pairs and those who did the task individually (68.05\% vs. 62\%). Considering the fact that the pairs had spent more time on completing the task, one would have expected a greater level of accuracy compared to those who did the task individually. Nevertheless, as Storch (2007: 155) concedes, "these results may be due to the small number of items included in the task itself, and the small number of tokens of some features such as articles and word forms."

More recently and in an EFL setting, Baleghizadeh (2009) compared Iranian intermediate learners' performance on a conversational cloze task under two conditions: individually versus collaboratively. The given cloze task consisted of three types of gaps, namely articles, prepositions, and coordinating conjunctions. The findings revealed that the learners' overall performance in the collaborative mode was significantly better than their performance in the individual mode. However, further analysis indicated some differences across the three given grammatical forms. While the learners who had worked in pairs outperformed their peers in the individual mode on articles and prepositions, their performance on coordinating conjunctions did not significantly differ. It is concluded that this might be due to the complex nature of grammar rules related to articles and prepositions compare to the simpler rules governing the use of coordinating conjunctions. "Apparently, more complex grammatical items (e.g., articles and prepositions) are better candidates to benefit from pair work than those which do not encompass a wide range of complicated rules" (Baleghizadeh, 2009:8). Another argument posed to account for this difference is the psycholinguistic readiness of the learners to negotiate more challenging forms like articles and prepositions, which has naturally resulted in their better performance through collaborative work.

\section{THE STUDY}

Given the contradictory findings of the small body of research on the impact of peer interaction on grammatical accuracy of learners, there is clearly a need for further research in this area. Given, further, that the previous studies were carried out in ESL contexts, this study sought to fill this void in the literature by investigating the benefits of pair work on a text editing activity in an EFL context. Therefore, the research questions that guided this study were as follows:

1) Do learners working in pairs do a text editing activity more accurately than those who do the same activity individually?

2) If so, do all grammatical features benefit from this interaction?

\section{METHOD}

\section{A. Participants}

The participants were 62 (22 male and 40 female) second and third year students of English Literature at Shahid Beheshti University, who volunteered to take part in this study. In order to determine the homogeneity of the participants in terms of their language proficiency, they were given a paper-based version of the TOEFL test, which showed that their scores were in the 560-585 range. The participants were then randomly assigned to experimental and 
control groups. 40 students formed the experimental group and 22 students constituted the control group. The reason for this uneven student numbers will be explained later.

\section{B. Material}

The material used in the study was a text editing activity adapted from Koch (1995) which required the participants to amend it. The text was 279 words long and contained 30 error items. The errors were related to the use of one of these function words: articles (10), prepositions (10), and subordinating conjunctions (10). The participants were required to add, delete or change one of these word categories to improve the accuracy of the text.

\section{Procedure}

The participants completed the given editing activity under two conditions: individually and collaboratively, i.e. in pairs. In the collaborative condition, students worked in self-selected pairs. Following Storch (1999), in order to encourage joint production, each pair was given only one copy of the activity. This suggests that the total number of copies collected from the experimental group was 20 and the samples collected from the control group were 22.The participants in both groups were not pressed for time, i.e. they were given as much time as they would need to complete the activity. The average time spent on editing the text for the individual and collaborative modes were 20 and 24 minutes, respectively. This is rather surprising compared to similar studies in which the amount of time doubled when students worked in pairs than when they attempted individually (Storch, 1999, 2005, 2007; Storch \& Wigglesworth, 2007).

The participants in the experimental group were encouraged to cooperate with each other while doing the activity, and the researcher monitored them to make sure that they would speak in English. No attempt was made to audiotape the students' pair talk; however, the researcher made sporadic notes as he listened to some of the pairs.

\section{Data Analysis}

A multivariate analysis of variance (MANOVA) was used to compare the overall performance of the two groups on the text editing activity. Moreover, separate univariate F tests were employed to determine if there was any significant difference between the two groups on any of the function word categories, i.e. articles, subordinating conjunctions, and prepositions. The data analysis was carried out using the SPSS statistical software package (version 13) with alpha set at .05 .

\section{RESULTS}

Table 1 reports the means and standard deviations of control and experimental groups for their total and individual function word scores.

TABLE 1.

MEANS AND STANDARD DEVIATIONS FOR TOTAL AND INDIVIDUAL FUNCTION WORD SCORES

\begin{tabular}{|c|c|c|c|c|c|c|c|c|c|}
\hline \multirow[b]{2}{*}{ Group } & \multicolumn{2}{|c|}{ Total } & \multicolumn{2}{|c|}{ Articles } & \multicolumn{2}{|c|}{ Sub. Conjs. } & \multicolumn{2}{|c|}{ Preps. } & \multirow[b]{2}{*}{$S D$} \\
\hline & $n$ & $M$ & $S D$ & $M$ & $S D$ & $M$ & $S D$ & $M$ & \\
\hline Exp. & 20 & 22.95 & 2.60 & 7.50 & 1.27 & 7.35 & 1.18 & 8.10 & 1.11 \\
\hline Cont. & 22 & 15.72 & 2.58 & 3.86 & 1.45 & 4.55 & 1.56 & 7.32 & 1.49 \\
\hline
\end{tabular}

A MANOVA was run indicating the three dependent measures of articles, subordinating conjunctions, and prepositions. The Wilkis's Lambda test $F=34.83, p=.001$ resulted in a significant main effect for the pair work. This suggests that the mean score gained for the experimental group $(M=22.95)$ is significantly higher than the mean score of the control group $(M=15.72)$. Therefore, the first research question was answered in the positive; that is, students who had completed the task in pairs had outperformed those who had done it individually.

To answer the second research question, i.e. if all grammatical features would benefit from peer interaction, univariate $F$ tests for all three categories of function words were employed. Table 2 shows the results of these univariate $F$ tests.

TABLe 2.

UNIVARIATE $F$ TEST FOR ARTICLES, SUBORDINATE CONJUNCTIONS, AND PREPOSITIONS

\begin{tabular}{|c|c|c|c|c|c|c|}
\hline Source & Score & $d f$ & $S S$ & $M s$ & $F$ & Sig \\
\hline \multirow{3}{*}{ Pair work } & articles & 1 & 138.52 & 138.52 & $73.30^{*}$ & .001 \\
\hline & sub. conjs. & 1 & 82.40 & 82.40 & $42.25^{*}$ & .001 \\
\hline & preps. & 1 & 6.40 & 6.40 & 3.63 & .064 \\
\hline \multirow{3}{*}{ Error } & articles & 40 & 75.60 & 1.89 & & \\
\hline & sub. conjs. & 40 & 78.00 & 1.95 & & \\
\hline & preps. & 40 & 70.57 & 1.76 & & \\
\hline
\end{tabular}

The univariate test for articles revealed that there was a significant difference between students' mean scores on articles when they worked in pairs than when they worked individually, $F(1,40)=73.30, p<.05$. Similarly, the 
univariate test for subordinating conjunction resulted in a significant main effect for pair work, $F(1,40)=42.25, p$ $<.05$. Nevertheless, the univariate test for prepositions showed no significant difference between the groups, $F(1,40)=$ $3.63, p=.064$. This indicates that students did not benefit from pair work that much when it came to prepositions.

\section{DISCUSSION}

This study explored the efficacy of pair work in EFL classes by comparing the performance of pairs and individuals on a text editing activity. The analysis showed that when students completed the activity in pairs, their joint effort was more successful. This suggests that, overall, students benefited from negotiated interaction. The following excerpt, noted down by the researcher as he listened to one of the pairs, shows that students' negotiation typically tended to center on grammatical forms.

S1: Another problem ... the Rhode Island. It doesn't need the.

S2: But we say the Kish Island, and ...

S1: No, No. I'm sure. My teacher said don't use the with islands. It's Rhode Island.

S2: Ok, so correct it. Rhode Island.

This is a clear instance of negotiation of form produced through the process of interaction. Student 2 , through the feedback that he receives, modifies his output on "the Kish Island" and admits that he should use zero article before the names of islands, and that is why he finally says "Rhode Island." It follows, therefore, that pair work provides learners with opportunities to engage in the kind of moves that have been hypothesized by the interaction hypothesis to be facilitative of second language learning: seeking and receiving confirmation, providing each other with negative feedback, etc.

As for the second research question, i.e. which grammatical features would benefit from negotiated interaction, this study offers interesting findings. As shown in Table 2, the grammatical problems concerning articles and subordinating conjunctions were resolved more successfully when attempted collaboratively than individually, while pair work was not any better than individual work regarding problems pertaining to the use of prepositions. This indicates that negotiated interaction helps learners with certain grammatical features. One possible explanation for this phenomenon is that more complex grammatical items, such as articles and subordinating conjunctions, are more likely to be affected by beneficial effects of interaction than more straightforward grammatical items like prepositions. It should be noted that the majority of prepositional problems addressed in this study were transparent cases, e.g. in is the only preposition used after believe or on is the only preposition used after based (see Appendix A). This could be the reason why students' performance on them did not differ that much when attempted in either of the two modes (individual vs. collaborative).

The findings of this study corroborate the findings of Storch (1999) but do not lend support to those of Storch (2007) in that, overall, learners completed the task more successfully in pairs than individually. However, as for different grammatical forms, the present study supports neither of Storch's studies. The learners' pair work on the use of articles in this study seems to have benefited them more than individual work compared to Storch's studies. The results are also partially similar to the findings of Baleghizadeh (2009) in that the participants' overall performance in the collaborative mode was significantly better than their performance in the individual mode. Moreover, those working in pairs were able to correct more article and subordinating conjunction errors than those working alone. However, regarding prepositions their performance did not significantly differ, whereas in Baleghizadeh (2009) there was a significant difference between the two groups on prepositions. This might be due to the transparent use of prepositions in the given task, which was mentioned above.

One last interesting finding of this study is concerned with the time factor. As mentioned earlier, the time spent on doing the activity in pairs was only four minutes longer than when it was done individually, whereas in similar studies conducted previously, this time doubled. That is why the improved accuracy of students working in pairs in many of the previous studies (Storch, 1999, 2005, 2007) cannot be merely attributed to the beneficial effects of negotiated interaction. As Storch (1999: 370) observes, "this improved accuracy may be due to the longer time students spent on the exercises when completing them in pairs." However, due to the insignificant time difference (only four minutes) between the performance of the two groups, the findings of the present study lend stronger support to the facilitative role of negotiated interaction.

\section{CONCLUSION}

The findings of this study suggest that urging EFL learners to do grammar-focused activities in pairs is likely to result in mixed effects on grammatical accuracy: a positive effect on their overall performance but a varying effect on certain grammatical features. Therefore, not all grammatical items benefit from negotiated interaction. Apparently, more complex grammatical items (e.g. articles) are in a better position to enjoy this type of treatment. Nevertheless, the small number of tokens (only 10) for each grammatical feature restricts any further generalization. One thing, however, is clear: when learners pool their linguistic resources together, they are more likely to co-construct knowledge and resolve linguistic problems. That is why their accuracy increases when they interact with a peer. One important pedagogical implication of this study, therefore, is that pair work activities should no longer be the prerogative of 
conversation classes. As the findings of this study indicate, students can also benefit from pair work that encourages them to interact over grammar-focused activities.

\section{APPENDIX A}

Find and correct the errors in the following text.

Among conscientious objectors are the Quakers, also known as the Religious Society of Friends. Quaker religion originated from seventeenth-century England with George Fox, who believed what a person needs no spiritual intermediary. He sought to know that a person finds understanding and guidance and concluded which it is through an "inward light," supplied by Holy Spirit. The early Quakers refused to attend the Church of England services or to pay tithes to church. They questioned which the real values in life were, and they were frugal and plain on their dress and speech. In those times, whomever opposed customs of the established church was persecuted. Thus, the Quakers met with fines, confiscation of property, and even imprisonment. Some emigrated to Asia and Africa, but particularly to America, where they found refuge in the Rhode Island and in Pennsylvania, a colony established in 1682 by William Penn, who was himself a Quaker.

Quakers do not believe at taking part of war because they feel that war causes spiritual damage from hatred. Most Quakers refuse to serve in military, although individuals can follow however convictions they personally hold. Because their resistance is based at religious and humanitarian convictions, U.S. and British governments have allowed them to substitute nonmilitary service with that would normally be military service requirement.

Quaker meetings are periods of silent meditation, where members speak if they are urged to spirit. Quakers are active at education and social welfare. They believe the society should treat all its citizens as equals. The American Friends Service Committee organizes relief and service projects at whatever in the world help is needed.

\section{REFERENCES}

[1] Ayoun, D. (2001). The role of negative and positive feedback in the second language acquisition of the passé composé and imparfait. Modern Language Journal, 85, 226-243.

[2] Balegizadeh, S. (2009). Investigating the effectiveness of pair work on a conversational cloze task in EFL classes. TESL Reporter, 42(1), 1-12.

[3] Braidi, S. (2002). Reexamining the role of recasts in native-speaker/nonnative-speaker interaction. Language Learning, 52, 142.

[4] Brown, H. D. (2001). Teaching by principles: An integrative approach to language pedagogy. New York: Addison Wesley Longman.

[5] Crookes, G., \& Chaudron, C. (2001). Guidelines for language classroom instruction. In M. Celce-Murcia (Ed.), Teaching English as a second or foreign language. Boston: Heinle \& Heinle.

[6] Davis, R. (1997). Group work is NOT busy work: Maximizing success of group work in the L2 classroom. Foreign Language Annals, 30, 265-279.

[7] Gass, S. (1997). Input, interaction, and the second language learner. Mahwah, NJ. : Lawrence Erlbaum.

[8] Gass, S., \& Mackey, A. (2006). Input, interaction and output. AILA Review, 19, 3-17.

[9] Gass, S., \& Mackey, A. (2007). Input, interaction, and output in second language acquisition. In B. VanPatten \& J. Williams (Eds.), Theories in second language acquisition. Mahwah, NJ. : Lawrence Erlbaum.

[10] Gass, S., Mackey, A., \& Pica, T. (1998). The role of input and interaction in second language acquisition. Modern Language Journal, 82, 299-307.

[11] Harmer, J. (2001). The practice of English language teaching. Harlow: Longman.

[12] Hatch, E. (1978). Acquisition of syntax in a second language. In J. C. Richards (Ed.), Understanding second and foreign language learning. Rowley, MA: Newbury House.

[13] Koch, R. (1995). Focus on grammar (advanced): workbook. New York: Addison Wesley Longman.

[14] Krashen, S. D. (1982). Principles and practice in second language acquisition. Oxford: Pergamon.

[15] Leeman, J. (2003). Recasts and second language development: Beyond negative evidence. Studies in Second Language Acquisition, 25, 37-63.

[16] Long, M. (1983). Native speaker/non-native speaker conversation in the second language classroom. In M. Clarke \& J. Handscombe (Eds.), On TESOL'82: Pacific perspectives on language and teaching. Washington, D. C.: TESOL.

[17] Long, M. (1985). Input and second language acquisition theory. In S. Gass \& C. Madden (Eds.), Input in second language acquisition. Rowley, MA: Newbury House.

[18] Long, M. (1996). The role of the linguistic environment in second language acquisition. In W. Ritchie \& T. Bhatia (Eds.), Handbook of second language acquisition. New York: Academic Press.

[19] Long, M., \& Porter, P. (1985). Group work, Interlanguage talk, and second language acquisition. TESOL Quarterly, 19, 207227.

[20] Lyster, R. (1998a). Negotiation of from, recasts, and explicit correction in relation to error types and learner repair in immersion classrooms. Language Learning, 48, 183-218.

[21] Lyster, R. (1998b). Recasts, repetition and ambiguity in L2 classroom discourse. Studies in Second Language Acquisition, 20, 51-81.

[22] Mackey, A. (1999). Input, interaction, and second language development: An empirical study of question formation in ESL. Studies in Second Language Acquisition, 21, 557-587. 
[23] Mackey, A. (2007). Interaction as practice. In R. M. DeKeyser (Ed.), Practice in a second language: Perspectives from applied linguistics and cognitive psychology. Cambridge: Cambridge University Press.

[24] Mackey, A., Gass, S., \& McDonough, K. (2000). How do learners perceive interactional feedback? Studies in Second Language Acquisition, 22, 471-497.

[25] Mackey, A., \& Philp, J. (1998). Conversational interaction and second language development: Recasts, responses, and red herrings? Modern Language Journal, 82, 338-356.

[26] McDonough, K. (2005). Identifying the impact of negative feedback and learners' responses on ESL question development. Studies in Second Language Acquisition, 27, 79-103.

[27] Muranoi, H. (2007). Output practice in the L2 classroom. In R. DeKeyser (Ed.), Practice in a second Language: Perspectives from applied linguistics and cognitive psychology. Cambridge: Cambridge University Press.

[28] Nicholas, H., Lightbown, P., \& Spada, N. (2001). Recasts as feedback to language learners. Language Learning, 51, $719-758$.

[29] Oliver, R., \& Mackey, A. (2003). Interactional context and feedback in child ESL classrooms. Modern Language Journal, 87, 519-533.

[30] Pica, T. (1994). Research on negotiation: What does it reveal about second language learning conditions, processes, and outcomes? Language Learning, 44, 493-527.

[31] Pica, T. (1996). Do second language learners need negotiation? International Review of Applied Linguistics, 34, 1-21.

[32] Pica, T., Young, R., \& Doughty, T. (1987). The impact of interaction on comprehension. TESOL Quarterly, 21, 737-758.

[33] Schmidt, R. (1990). The role of consciousness in second language learning. Applied Linguistics, 11, 129-158.

[34] Shehadeh, A (2002). Comprehensible output, from occurrence to acquisition: An agenda for acquisitional research. Language Learning, 52,597-647.

[35] Storch, N. (1999). Are two heads better than one? Pair work and grammatical accuracy. System, 27, 363-374.

[36] Storch, N. (2005). Collaborative writing: Product, process, and students' reflections. Journal of Second Language Writing, 14, 153-173.

[37] Storch, N. (2007). Investigating the merits of pair work on a text editing task in ESL classes. Language Teaching Research, 11,143-159.

[38] Storch, N. \& Wigglesworth, G. (2007). Writing tasks: The effects of collaboration. In M. Garcia Mayo (Ed.), Investigating tasks in formal language settings. Clevedon: Multilingual Matters.

[39] Swain, M. (1995). Three functions of output in second language learning. In G. Cook \& B. Seidlhofer (Eds.), Principle and practice in applied linguistics. Oxford: Oxford University Press.

[40] Swain, M. (2005). The output hypothesis: Theory and research. In E. Hinkel (Ed.), Handbook on research in second language learning and teaching. Mahwah, NJ: Lawrence Erlbaum.

[41] Swain, M., Brooks, L., \& Tocalli-Beller, A. (2002). Peer-peer dialogue as a means of second language learning. Annual Review of Applied Linguistics, 22, 171-185.

Sasan Baleghizadeh is an Assistant Professor of TEFL at Shahid Beheshti University, G.C. of Iran, where he teaches applied linguistics, syllabus design, and materials development. He is also a member of the Research and Planning Department at the Iran Language Institute, where he designs, develops, and edits English language examinations and teaching materials. His recent publications have appeared in TESL Reporter, ELT Journal, and Novitas-ROYAL. 